УДК 342

Ю. Ю. Швець

\title{
ПРОБЛЕМИ РЕАЛІЗАЦІї КОНСТИТУЦЙНО ПРАВА ОСОБИ НА ОХОРОНУ ЗДОРОВ'Я: СУЧАСНИЙ ПОГЛЯД
}

Постановка проблеми. У сучасних умовах державного розвитку нової актуальності набуває проблема забезпечення реалізації конституційних прав людини та громадянина. Так, одним із завдань підписання Угоди про асоціацію між Україною та ЄС [1] визначено зміцнення поваги зі сторони держави та міжнародного співтовариства до демократичних принципів, прав людини та основоположних свобод, закріплених у міжнародних документах. Європейський вибір, зроблений Україною, обумовив проведення ряду реформ, спрямованих на виконання цього завдання, включаючи також і реформу галузі охорони здоров'я. Однак для того, щоб заплановані зміни мали високий ступень ефективності, необхідно виходити із практичних проблем, наявних у галузі, та можливих способів їх вирішення.

При цьому слушною видається думка М.В. Савчина, який справедливо зауважує, що часто здобутки конституційної доктрини не спираються на дані емпіричних досліджень, які б враховували динаміку конституційних правовідносин, фактори, що впливають на поведінки їх учасників (мотивацію, ціннісні орієнтири), співвідношення індивідуального, корпоративного і загального інтересу, що дає синергетичний ефект. і його наслідки спрогнозувати за лінійними методиками складно [2, с. 5].

Тому проведення конституційної реформи у сфері охорони здоров'я має спиратися на цілком конкретні цілі. Зокрема, основним мотиваційним фактором, який визначив необхідність у проведенні трансформаційний змін у даній галузі, став незадовільний стан дотримання права особи на охорону здоров'я, що передусім пов'язано з проблемами різнопланового характеру, що виникають у процесі реалізації зазначеного права.

Таким чином, метою даної статті є дослідження основних проблем, пов'язаних із реалізацією конституційного права особи на охорону здоров'я, та визначення можливих шляхів вирішення виявлених проблем.

Виклад основного матеріалу. Для досягнення поставленої мети передусім слід уточнити критерії належної реалізації права особи на охорону здоров'я, що має стати відправною точкою для виявлення відповідних проблем. 
Так, деякі зарубіжні вчені акцентують увагу на тому, що право на охорону здоров'я не є абсолютним, оскільки ефективність його реалізації залежить від багатьох факторів: по-перше, конкретних дій держави в цьому напрямку; по-друге, здатності функціонуючих адміністративних та інституційних систем належним чином виконувати покладені на них функції; по-третє, від сприйняття таких дій суспільством. Також суттєвим фактором є поведінка та спосіб життя самої людини - члена суспільства [3, с. 282].

На цій підставі можна констатувати, що реалізація права на охорону здоров'я потребує активних дій, як зі сторони компетентних державних органів, їх службових та посадових осіб, закладів та установ охорони здоров'я, медичних працівників, так і осіб, як носіїв відповідного права, а також наявності належних умов для здійснення таких дій.

У міжнародних документах ООН наводяться такі умови належної реалізації права особи на охорону здоров'я: 1) усі послуги, товари та об'єкти у сфері медицини повинні бути доступними та якісними; 2) заходи охорони здоров'я, а також медичні товари та послуги повинні бути доступні та забезпечені в достатній кількості державою; 3) вони повинні бути доступними фізично, а також фінансово на засадах рівності та недискримінаціі; 4) наявність правил медичної етики та культури та їх дотримання працівниками галузі охорони здоров'я; 5) медичні засоби, допомога та інші види медичних послуг повинні бути науково обгрунтованими та доцільними, а також бути належної якості $[4$, с. 4$]$.

У переважній більшості випадків причиною порушення права особи на охорону здоров'я стає саме відсутність у державі означених вище умов. Відповідно, проблеми реалізації даного права необхідно шукати передусім у неналежному забезпеченні таких умов державою або іншими суб'єктами, зобов'язаними відповідно до законодавства виконувати функції в цій сфері.

На основі аналізу деяких статистичних показників можна дійти до висновку, що однією з найбільш серйозних проблем сучасної організації галузі охорони здоров'я респонденти вважають діючу система управління цією галуззю. Зокрема, така проблема виокремлена більше, ніж $60 \%$ учасників опитування [5, с. 195]. Характерно, що основними соціальними цінностями, які мають бути притаманними оновленій системі охорони здоров'я, респонденти вважають покращення життя пацієнтів - більше $90 \%$ опитаних, що закладено у вільному виборі ними лікаря та лікувального закладу. Усе це буде сприяти повноцінному одужанню пацієнтів, як вважають біля $83 \%$ респондентів [5, с. 195$]$.

Таким чином, критерії належної реалізації права особи на охорону здоров'я доцільно поділити на дві групи: загальні, які відображають національні показники ефективності, тобто показники на рівні держави, та індивідуальні, за допомогою яких можливо оцінити стан реалізації права на охорону здоров'я відносно кожної конкретної особи. До перших слід віднести: 1) тривалість життя населення; 2) рівень та структуру захворюваності; 3) рівень задоволення потреб населення у сфері охорони здоров'я; 
4) рівень екологічної безпеки в державі; 5) рівень фінансування системи охорони здоров'я тощо. Ці показники можливо оцінити лише в порівнянні з аналогічними показниками в інших державах світу.

До другої групи критеріїв відносяться: 1) територіальна та фінансова доступність медичної допомоги та інших медичних послуг, включаючи медичні препарати, лікарські засоби тощо, для кожної особи; 2) об'єктивна та фактична можливість отримання кваліфікованої та професійної медичної допомоги в разі виникнення потреби; 3) можливість захистити порушене право на охорону здоров'я національними засобами - в судовому або позасудовому порядку тощо.

Оцінюючи сучасний стан системи охорони здоров'я, виходячи з наведених вище критеріїв, та на підставі аналізу положень національного законодавства [6; 7] можна виокремити проблеми в цій сфері.

1. Недосконалість поточного стану правового регулювання права на охорону здоров'я та інші проблеми юридичного характеру, пов'язані із забезпеченням його реалізації.

Однією з нагальних проблем правового регулювання в досліджуваній сфері $€$ відсутність уніфікованої термінології, а також легітимного визначення деяких понять та категорій у медичній сфері. На дану проблему, зокрема, звертають увагу В.В. Лещенко та Я.Ф. Радиш. Науковці пропонують удосконалене визначення таких понять, як «державне управління охороною здоров'я», «громадське здоров'я», «єдиний медичний простір», та вважають, що їх дефініції мають бути визначені в Основах законодавства України про охорону здоров'я [8, с. 112].

Погоджуючись з означеним зауваженням, важливо також акцентувати увагу на тому, що особливо гостро проблема вдосконалення правового регулювання права на охорону здоров'я постає у зв'язку з необхідністю узгодження національних стандартів у сфері охорони здоров'я з європейськими.

Із цього приводу В.С. Віткова вказує на нагальну потребу європеїзації юридичного забезпечення права на медичну допомогу в Україні. На підставі дослідження практики Європейського Суду з прав людини вчена запропонує такі напрями європеїзації: 1) узгодження питання інформованої згоди пацієнта; 2) перегляд юридичного забезпечення права людини на стерилізацію; 3) вдосконалення правового врегулювання трансплантації органів та інших анатомічних матеріалів людині (органів, тканин, анатомічних утворень, клітин людини або тварини) [9, с. 180].

Крім того, на рівні Конституції України необхідне суттєве розширення змісту права особи на охорону здоров'я, а також потребує деталізації механізм реалізації деяких елементів цього права. Наприклад, у ч. 1 ст. 49 Конституції України визначено три основні складові елементи: право на охорону здоров'я, медичну допомогу та медичне страхування. При цьому в статті взагалі не згадується про права пацієнтів та деякі інші елементи.

Також слід звернути увагу, що реалізація закріпленого в ст. 49 Конституції України права на медичне страхування ускладняється фактичною 
відсутністю правової основи для цього, оскільки чинний на сьогодні Закон України «Про страхування» [10] не в повній мірі враховує всі особливості даної галузі страхування. У той же час законопроект «Про загальнообов'язкове державне соціальне медичне страхування в Україні» від серпня 2016 р. реєстр. № 4981-2 [11] наразі перебуває на розгляді у Верховній Раді Україні та, за висновком Головного науково-експертного управління [12], потребує доопрацювання, зокрема в частині наявності невідповідності окремих положень законопроекту міжнародним принципам рівноправності громадян, демократизму і загальнодоступності медичної допомоги тощо. Тож на сьогодні залишається неврегульованим питання реалізації права на медичне страхування, гарантоване та захищене державою.

2. Недостатня якість, професійність та доступність надання медичної допомоги та інших видів медичних послуг.

Як зазначає із цього приводу К.Г. Головачова, на сьогодні в Україні, гостро стоїть проблема надання медичної допомоги високої якості кваліфікованими спеціалістами. Також потребує вирішення питання доступності медичної допомоги в Україні, що передбачає баланс багатьох факторів: кадри, фінансування, технічні та транспортні засоби, свобода вибору, громадська просвіта, розподіл технічних ресурсів [13, с. 81, 83].

Погоджуючись із наведено точкою зору, необхідно також акцентувати увагу на тому, що стандарти у сфері перевірки кваліфікації медичних працівників в Україні є дещо застарілими. Зокрема, на сьогодні залишаються чинними накази Міністерства охорони здоров'я України «Про порядок направлення на стажування лікарів і їх наступного допуску до лікарської діяльності» від 17 березня 1993 р. № 48 [14] та «Про подальше вдосконалення атестації лікарів» від 19 грудня 1997 р. № 359 [15].

У Наказі № 359 визначено три види атестації лікарів: атестація на визначення знань і практичних навиків з присвоєнням (підтвердженням) звання «лікар-спеціаліст»; атестація на присвоєння кваліфікаційної категорії; атестація на підтвердження кваліфікаційної категорії. Звертає на себе увагу той факт, що атестація на підтвердження кваліфікаційної категорії проводиться раз на п'ять років, при цьому підстав для дострокового іiі призначення не передбачено (наприклад, у разі надходження скарги від пацієнтів; порушення правил медичної етики тощо).

Із цього приводу варто зазначити, що за законодавством багатьох європейських країн передбачається обов'язкове індивідуальне ліцензування лікарської діяльності, незалежно від того, в якому медичному закладі він працює (державному або приватному). При цьому, наприклад, у Німеччині вперше ліцензія видається на невизначений строк. Однак на лікарів покладається обов'язок так званого безперервного продовження медичної освіти та постійного підвищення кваліфікації, а у випадку серйозних порушень лікарем своєї професійної етики орган ліцензування може призупинити або відкликати ліцензію. Залежно від характеру правопорушень до особи можуть застосуватися й інші санкції, а саме: попередження, штраф, тимчасове усунення від справ і анулювання ліцензії [16]. 
Крім того, для підвищення якості та професійності надання медичної допомоги в Україні необхідне формування національної моделі управління якістю медичної допомоги, яка, на думку деяких фахівців, має включати: створення оптимальної структури для надання медичної допомоги (будівлі, кадри, обладнання, витратне майно, медикаменти); організацію і управління медичними технологічними процесами; управління результатами надання допомоги; використання інформаційно-обчислювальних технологій; безперервне навчання персоналу; диференціацію оплати праці: залежність заробітної плати від підвищення якості [17, с. 131].

3. Малоефективна система організації та державного управління галуззю охорони здоров'я, включаючи здійснення державного контролю за якістю надання медичних послуг, дотримання стандартів та етичних вимог у закладах охорони здоров'я всіх форм власності.

Так, одним із принципів, визначених у ст. 4 Основи законодавства України про охорону здоров'я, є децентралізація державного управління, розвиток самоврядування закладів та самостійності працівників охорони здоров’я на правовій і договірній основі. Водночас у ст. 13 цього ж законодавчого акта фактично йде про централізоване формування державної політики у сфері охорони здоров'я; відповідні засади також закріплені в ст. ст. 85, 92 Конституції України. Крім того, для практичної реалізації принципу децентралізації державного управління та розвитку медичного самоврядування потрібна чітка правова основа (наразі розроблений законопроект «Про лікарське самоврядування» [18]), а також зміна механізмів фінансування. Тому порушене питання необхідно розглядати в безпосередньому зв'язку з наступною проблемою.

4. Проблеми у сфері фінансування сфери охорони здоров'я, що включає також недостатне матеріально-технічне та спеціалізоване оснащення лікарень, інших закладів та установ охорони здоров'я, незадовільний рівень оплати праці працівників медичної галузі тощо.

А. Гук та В. Галайда зауважують, що проблеми діючої на сьогодні в Україні системи фінансування сфери охорони здоров'я полягають у наступному: 1) недостатнє фінансування галузі охорони здоров'я; 2) відсутність визначеного законодавством та нормативно-правовими актами переліку послуг, які повинні надаватись громадськими закладами охорони здоров'я безоплатно при кожному даному рівні фінансування цих закладів; 3) відсутність зв'язку між фінансуванням громадських закладів охорони здоров'я і кінцевими результатами їх роботи $[19$, с. 16]. У Концепції реформи фінансування системи охорони здоров'я вказується на такі основні проблеми у фінансуванні системи охорони здоров'я: 1) катастрофічна фінансова незахищеність пацієнтів; 2) низька якість та ефективність надання послуг; 3) неефективне витрачання бюджетних коштів. Неефективність витрачання коштів пов'язана передусім з їх витрачанням не за принципом «гроші ходять за пацієнтом», а за принципом «гроші ходять за інфраструктурою» [20].

Для вирішення проблем, що виникають у сфері фінансування галузі охорони здоров'я, Верховною Радою України 19 жовтня 2017 р. прийнято 
Закон України «Про державні фінансові гарантії надання медичних послуг та лікарських засобів» [21] (ще не набув чинності). Однак і він містить ряд спірних питань, які потребують уточнення та узгодження з конституційною гарантією, відповідно до якої медична допомога в комунальних та державних закладах охорони здоров'я надається безкоштовно.

5. Відсутність комплексного підходу в забезпеченні реалізації права особи на охорону здоров'я.

Означена проблема грунтується на тому факті, що право особи на охорону здоров'я тісно пов'язане з іншими конституційними правами - $€$ передумовою або наслідком їх реалізаціі. Тому розв'язання проблем, що виникають у процесі реалізації права на охорону здоров'я, потребують комплексного підходу, що передбачає підвищення рівня життя населення, його соціально-економічного добробуту, екологічної ситуації в країні тощо.

Таким чином, за результатами проведеного дослідження слід зазначити, що недостатня ефективність реалізації конституційного права особи на охорону здоров'я пов'язана з такими основними проблемами: 1) недосконалістю законодавчого регулювання як самого права на охорону здоров'я, визначений зміст якого не в повній мірі відповідає потребам сучасності, так і механізму (процедур) реалізації окремих елементів даного права (на медичне страхування, судовий захист прав пацієнтів тощо); 2) неефективною системою організації та управління галуззю охорони здоров'я; 3) неефективною системою фінансування галузі; 4) недостатньою якісністю та професійністю медичної допомоги та інших видів медичних послуг, які часто не відповідають європейським стандартам; 5) відсутністю комплексного підходу у сфері реалізації права на охорону здоров'я, що передбачає забезпечення ефективного функціонування механізмів реалізації всіх суміжних конституційних прав особи, від яких у певній мірі залежить реалізація досліджуваного права - на достатній життєвий рівень, екологічне благополуччя тощо.

Висновки. Для усунення виявлених проблем у найближчій перспективі можна запропонувати: 1) перше речення ч. 3 ст. 49 Конституції України викласти в такій редакції: «Держава створює умови для ефективного, якісного і доступного для всіх громадян медичного обслуговування та дотримання прав пацієнтів»; 2) внести такі доповнення до Основ законодавства України про охорону здоров'я: в ст. 22 уточнити форми державного контролю та нагляду (проведення атестації медичних працівників, ліцензування, проведення перевірок тощо); в ст. 24-1 навести основний перелік прав пацієнтів (повагу до честі та гідності, інформацію про стан здоров'я, отримання кваліфікованої, своєчасної та доступної медичної допомоги, на стаціонарне лікування тощо); 3) у Розділі IV Положення про порядок проведення атестації лікарів визначити механізм дострокового (частіше, ніж 1 раз на 5 років) проведення атестації на підтвердження кваліфікаційної категорії: визначити підстави для цього (надходження скарг на дії лікаря, службове розслідування тощо), порядок та наслідки проведення тощо. 


\section{Література}

1. Угоди про асоціацію між Україною, з однієї сторони, та Європейським Союзом, Європейським співтовариством з атомної енергії і їніми державами-членами, з іншої сторони: Міжнародний документ від 27.06.2014 [Електронний ресурс]. - Режим доступу : http: / / zakon3.rada.gov.ua / laws/show/984_011

2. Савчин М.В. Конституціоналізм і природа конституції: монографія / М.В. Савчин. Ужгород : Поліграфцентр «Ліра», 2009. - 372 с.

3. Čelkis P. Concept of the right to health care / P. Čelkis, E. Venckiené / / Jurisprudencija. 2011. - № 18(1). - P. 269-286.

4. The Right to Health / / Office of the United Nations High Commissioner for Human Right. 2008. - No. 31. - 52 p. - [Electronic resource]. - Access: http://www.ohchr.org/Documents/ Publications / Factsheet31.pdf.

5. Січкоріз О.Є. Медико-соціальне дослідження рівня компетентності організаторів охорони здоров'я львівщини стосовно реформування системи охорони здоров'я / О.Є. Січкоріз // Буковинський медичний вісник. - 2017. - Т. 21, № 2 (82). - С. 192.

6. Конституція України: Основний Закон України від 28.06.1996 № 254к/96-ВР [Електронний ресурс]. - Режим доступу : http://zakon3.rada.gov.ua/laws/show/254\%D0\%BA/96$\%$ D0 $\%$ B2 $\%$ D $1 \% 80$.

7. Основи законодавства України про охорону здоров'я: Закон України від 19.11.1992 № 2801-XII [Електронний ресурс]. - Режим доступу : http://zakon3.rada.gov.ua/laws/ show / 2801-12.

8. Лещенко В.В. Права людини на життя та охорону здоров'я - методологічна основа державного управління здоровоохоронною сферою: вступ до проблеми / В.В. Лещенко, Я.Ф. Радиш / / Державне управління: теорія та практика. - 2014. - № 1. - С. 104

9. Віткова В.С. Конституційне право на медичну допомогу та його юридичне забезпечення в Україні : дис. ... канд. юрид. наук : 12.00.02 / В.С Віткова. - Ужгород, 2017. - 208 с.

10. Про страхування : Закон України від 07.03.1996 № 85/96-ВР [Електронний ресурс]. Режим доступу : http: / / zakon3.rada.gov.ua/laws/show / 85/96-\%D0\%B2\%D1\% 80.

11. Про загальнообов'язкове державне соціальне медичне страхування в Україні : проект Закону реєстр. № 4981-2 від 02.08.2016 р. [Електронний ресурс]. - Режим доступу : http: / / w1.c1.rada.gov.ua/pls/zweb2/webproc4_1?pf3511=59862.

12. Висновок на проект Закону України «Про загальнообов'язкове державне соціальне медичне страхування в Україні» (№ 4981-2 від 02.08.2016р.): Висновок Головного науково-експертного управління [Електронний ресурс]. - Режим доступу : http://w1.c1.rada.gov.ua/pls/ zweb2 / webproc4_1?pf3511=59862.

13. Головачова К.Г. Проблеми реалізації прав пацієнтів на медичну допомогу в Україні / К.Г. Головачова / / Медичне право України: проблеми становлення та розвитку. Матеріали I Всеукраїнської науково-практичної конференції 19-20.04.2007, м. Львів. - С. 80.

14. Про порядок направлення на стажування лікарів і їх наступного допуску до лікарської діяльності : Наказ Міністерства охорони здоров’я України від 17.03.1993 № 48 [Електронний ресурс]. - Режим доступу : http:/ / zakon0.rada.gov.ua/laws/show/z0019-93.

15. Про подальше удосконалення атестації лікарів : Наказ Міністерства охорони здоров'я України від 19.12.1997 № 359 [Електронний ресурс]. - Режим доступу : http://zakon0.rada. gov.ua/laws/show/z0014-98/paran17\#n17.

16. Скасків Т. Індивідуальне ліцензування лікарської практики: погляд юриста та зарубіжний досвід / Т. Скасків / / Український медичний часопис. - 2017. - [Електронний ресурс]. Режим доступу : http:/ / www.umj.com.ua/wp/wp-content/uploads/2017/06/LitsenLikarav.pdf.

17. Серебряков О.М. Світовий досвід побудови системи якості медичної допомоги та необхідність їі впровадження у вітчизняну військову медицину / О.М. Серебряков / / Військова медицина України. - 2009. - Т. 9. - С. 127.

18. Про лікарське самоврядування : проект Закону від 28.12.2016 реєстр. № 5617 [Електронний pecypc]. - Режим доступу : http://w1.c1.rada.gov.ua/pls/zweb2/webproc4_1?pf3511=60835.

19. Гук А. Проблеми чинної системи фінансування галузі охорони здоров'я / А. Гук, В. Галайда / / Досвід країн Європи у фінансуванні галузі охорони здоров'я: уроки для України. 2014. - [Електронний ресурс]. - Режим доступу : http:/ / eeas.europa.eu/archives/delegations / ukraine / documents / virtual_library/14_reviewbook_uk.pdf. 
20. Про схвалення Концепції реформи фінансування системи охорони здоров'я: Розпорядження Кабінету Міністрів України від 30.11.2016 № 1013-р [Електронний ресурс]. - Режим доступу : http://zakon2.rada.gov.ua/laws/show/1013-2016-\% D1\%80.

21. Про державні фінансові гарантіі надання медичних послуг та лікарських засобів: проект Закону від 10.04.2017 реєстр. № 6327 [Електронний ресурс]. - Режим доступу : http:/ / w1.c1.rada.gov.ua/pls/zweb2/webproc4_1?pf3511=61566.

\section{Ано т а ц я}

Швець Ю. Ю. Проблеми реалізації конституційно права особи на охорону здоров'я: сучасний погляд. - Стаття.

Статтю присвячено висвітленню найбільш актуальних проблем сучасності у сфері забезпечення реалізації права особи на охорону здоров'я. Автором визначаються критерії належної реалізації даного права; виокремлюються проблеми, які виникають у процесі реалізації права на охорону здоров'я, та розробляються пропозиції щодо можливості їх усунення.

Ключові слова: конституційне право, охорона здоров'я, проблеми реалізації.

\section{Ан нот а ци я}

Швец Ю. Ю. Проблемы реализации конституционно права человека на охрану здоровья: современный взгляд. - Статья.

Статья посвящена освещению наиболее актуальных проблем современности в сфере обеспечения реализации права человека на охрану здоровья. Автором определяются критерии надлежащей реализации данного права; выделяются проблемы, возникающие в процессе реализации права на охрану здоров'я, и разрабатываются предложения по возможности их устранения.

Ключевые слова: конституционное право, здравоохранение, проблемы реализации.

\section{S u m m a r y}

Shvets $Y u$. Yu. Problems of constitutional implementation of the right of a person to health: a modern view. - Article.

The article is devoted to the coverage of the most pressing problems of the present in the sphere of ensuring the realization of the right of the person to health care. The author defines the criteria for the proper implementation of this right; the problems that arise in the process of realization of the right to health care are highlights and suggestions on the possibility of their elimination are developed.

Key words: constitutional law, health care, implementation problems. 